\title{
Looking east: Vincent van Gogh and Japan
}

\author{
CLIVE YOU
}

\section{Abstract}

During the formative years of his life in Arles, Vincent van Gogh became deeply enamoured with the art of Japan. This vision, while short-lived, was crucial for the eventual flowering of his unique painting style. Therefore, it is vital for us to understand the Japanese aesthetics and philosophy hidden in his paintings. This article commences with a discussion on the origins of van Gogh's Japonism interests, and then proceeds with an analysis of how this manifested itself in three periods of his 'Japanese Era', including where it drew on Japanese study, philosophy and utopia as well as paintings and prints. The visual analysis technique is widely utilised in this article to consider van Gogh's paintings and the Japanese influences on their colour, line, texture and size. The research shows that van Gogh established a rich connection to Japanese aesthetics and created the largest numbers of masterpieces of his career in his 'Japanese Era'.

\section{Origin}

Vincent van Gogh first expressed an interest in Japonaiserie in 1885 while he stayed in Antwerp. At that time, he already owned some Japanese prints; their exotic nature was the primary reason for his fondness of them. In one of his letters, he wrote that he was very much delighted by the Japanese prints he pinned on his walls.

Later, when he moved to Paris, he read far more about Japan, and studied a substantial number of Japanese prints. The countryside played a more important role in his career and in his existence as an artist because of the inspiration of peace and beauty that nature provided to his work. ${ }^{1}$ Eventually, while he lived in Arles, Japanese art and philosophy became major inspirations for van Gogh, affecting his paintings, behaviours and values.

1 Kōdera, Tsukasa, 'Japan as Primitivistic Utopia: Van Gogh's Japonisme Portraits', Simiolus: Netherlands Quarterly for the History of Art, vol. 14, no. 3/4 (1984), pp. 189-208. 


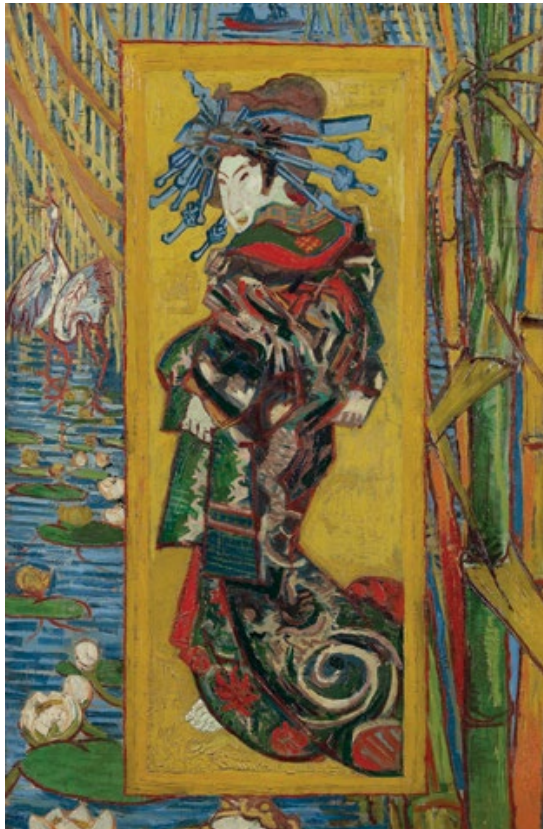

Figure 1: Vincent van Gogh (18531890), The Courtesan (after Eisen), Paris, October-November 1887, Oil on canvas, $100.7 \mathrm{~cm} \times 60.7 \mathrm{~cm}$.

Source: Van Gogh Museum, Amsterdam (Vincent van Gogh Foundation).

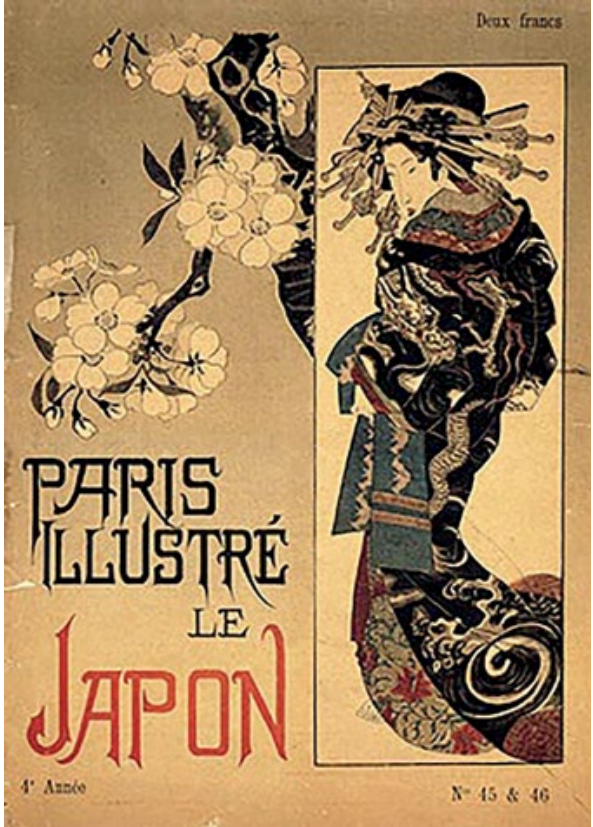

Figure 2: Title page of Paris Illustré 'Le Japon' vol. 4, May 1886, no. 45-46.

Source: Wikimedia Commons.

\section{The Courtesan (after Eisen)}

At the beginning of van Gogh's 'Japonisme période', he showed an interest in numerous oriental motifs, such as 'little women's figures, flowers, [and] knotty throw branches'. ${ }^{2}$ The Courtesan (Figure 1) is representative of his interest in Japanese women; he copied the exact figure of the original painting, but added his own concepts by incorporating his own artistic elements. The original artwork is called Courtesan Wearing Uchikake with Dragon Design by Kesai Eisen; it is a painting on a woodcut. Van Gogh did not directly copy from Kesai Eisen's painting; rather, he copied from the reproduction on the cover of Paris Illustré (Figure 2) in 1886. However, it is not a mere copy.

There are significant differences between the print and van Gogh's The Courtesan, including the use of colours and backgrounds. The colours in Kesai Eisen's version are relatively pale and dim, which reflects traditional Japanese aesthetics. The pure

2 Kōdera, Tsukasa, 'Japan as Primitivistic Utopia: Van Gogh's Japonisme Portraits', Simiolus: Netherlands Quarterly for the History of Art, vol. 14, no. 3/4 (1984), pp. 189-208. 
and vague qualities of the image show the impression of peace and tranquillity. In contrast, van Gogh used the technique of grids to copy and enlarge the Japanese figure and intensify the colour of her kimono, placing her against a bright yellow background. Furthermore, van Gogh arranged the central image by additionally painting a pond with frogs, waterlilies, cranes and bamboo stems. The bold outlines and bright colours create the appearance of a woodcut. More importantly, the objects in background have hidden meanings: grue (crane) and grenouille (frog) were French slang words for prostitute. ${ }^{3}$

In the same year, van Gogh made three copies from Japanese prints. One of these was Bridge in the Rain (Figure 3), which was a copy of Sudden Downpour on the Large Bridge near Atake (Figure 4). Van Gogh's copy is pretty close to the original piece, including the characters on the bridge, and the boat on the river. Nevertheless, he did intensify the colours and add the border around the edge. His interpretation of Japanese prints was more lively and chaotic.

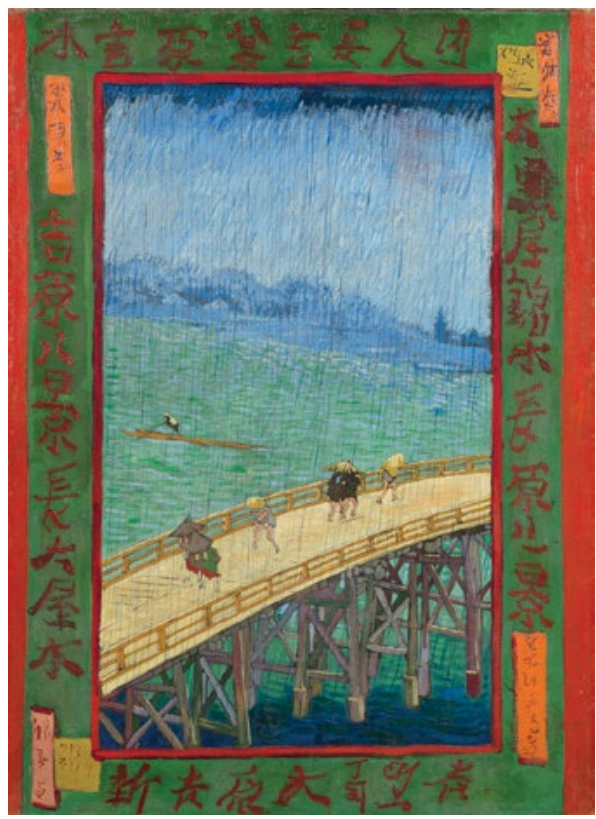

Figure 3: Vincent van Gogh (1853-1890), Bridge in the Rain (after Hiroshige), Paris, OctoberNovember 1887, oil on canvas, $73.3 \mathrm{~cm} \times 53.8 \mathrm{~cm}$.

Source: Van Gogh Museum, Amsterdam (Vincent van Gogh Foundation).

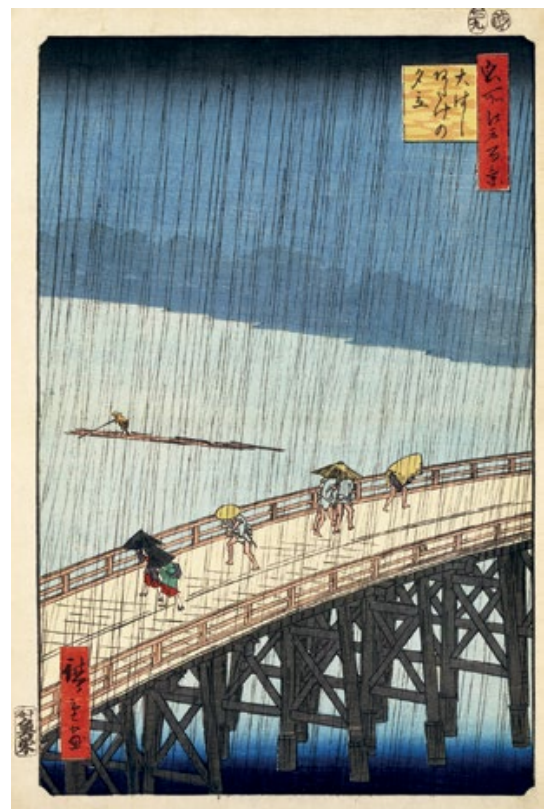

Figure 4: Utagawa Hiroshige, Sudden Downpour on the Large Bridge near Atake, 1857, woodcut, $34 \mathrm{~cm} \times 22 \mathrm{~cm}$.

Source: Van Gogh Museum, Amsterdam (Vincent van Gogh Foundation).

3 Courtesan (after Eisen), Van Gogh Museum, www.vangoghmuseum.nl/en/collection/s0116V1962 (accessed 9 October 2015). 


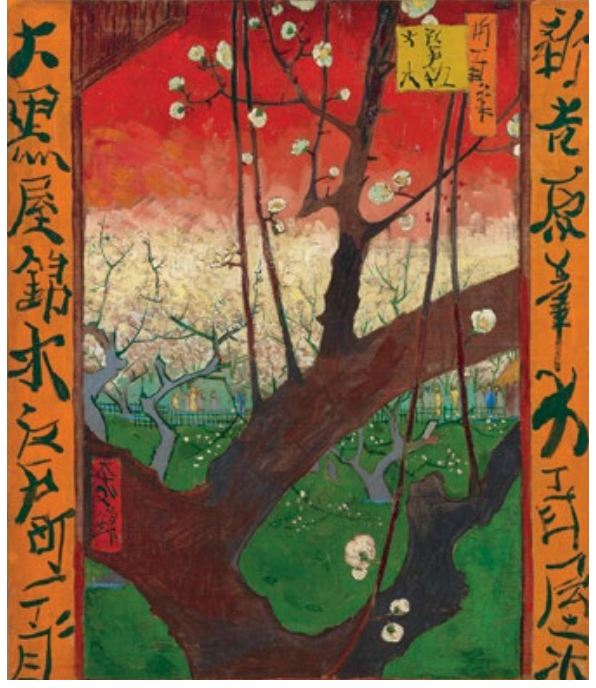

Figure 5: Vincent van Gogh (18531890), Flowering Plum Orchard (after Hiroshige), October 1887, oil on canvas, $55.6 \times 46.8 \mathrm{~cm}$.

Source: Van Gogh Museum, Amsterdam (Vincent van Gogh Foundation).

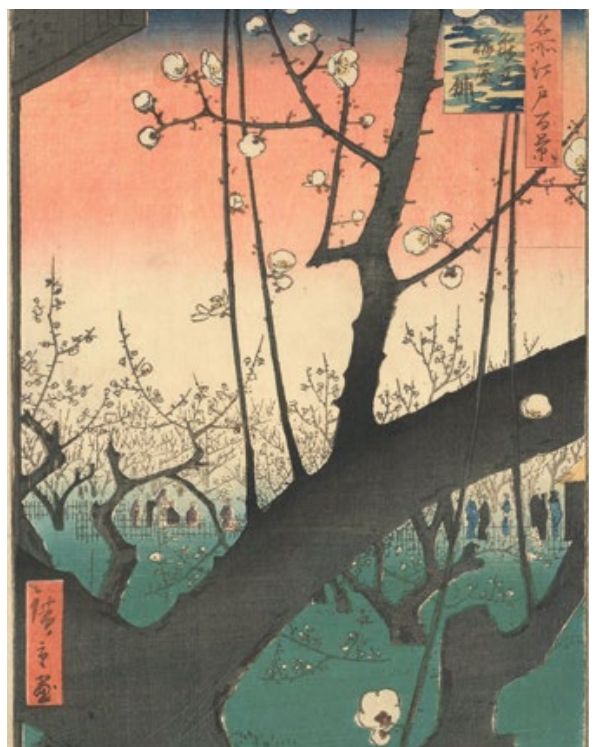

Figure 6: Utagawa Hiroshige, The Residence with Plum Trees at Kameido, 1857, woodcut, $34 \mathrm{~cm} \times 22 \mathrm{~cm}$.

Source: Van Gogh Museum, Amsterdam (Vincent van Gogh Foundation).

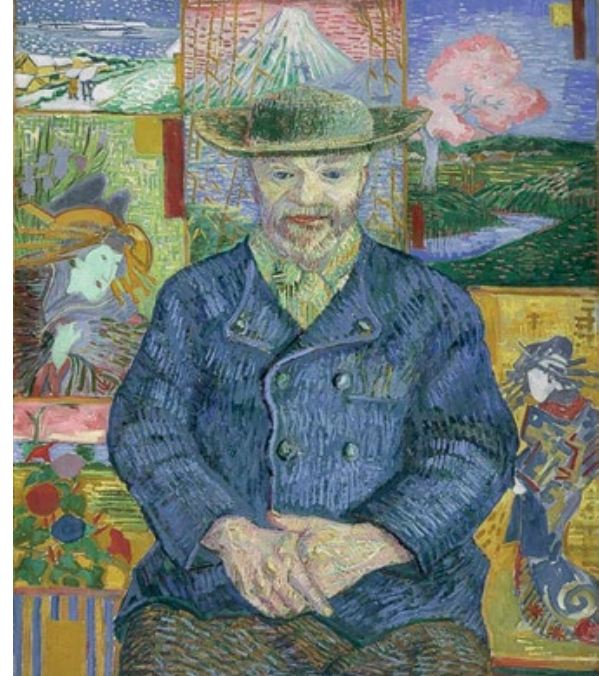

Figure 7: Vincent van Gogh (1853-1890), Portrait of Père Tanguy, 1887, Oil on canvas, $65.0 \mathrm{~cm} \times 51.0 \mathrm{~cm}$.

Source: Wikimedia Commons.

The third copy he made was Flowering Plum Orchard (after Hiroshige) (Figure 5), from The Residence with Plum Trees at Kameido (Figure 6). Similar to the first two copies, colour intensification and additional content around the border were used in this painting. Moreover, based on the comparison between these two pieces, I believe van Gogh was interested in the disjunction of the branches. In van Gogh's painting, it is easy to see that the features of tree branches and the teahouse are adapted from the original painting. 


\section{Portrait of Père Tanguy}

After 1885, 'Japan' became a luminous land and utopian world in van Gogh's mind. Van Gogh adopted a Japanese aesthetic in his painting Portrait of Père Tanguy (Figure 7). But how does the painting of an old art dealer relate to Japanese aesthetics? What do these annotations in the background signify?

First of all, let's analyse the image of the sitter-a man named Tanguy Julien François. Tanguy was a paint grinder, art dealer and also art supplier. ${ }^{4} \mathrm{He}$ was one of the first to provide van Gogh's artworks for sale. ${ }^{5}$ Tanguy, was described by his contemporary Emile Bernard in the following vivid account:

Julien Tanguy, who read Le Cri du Peuple and L'lntransigeant assiduously believed in the absolute love which brought all mankind together and destroyed the individual struggles of ambition, always so bitter and cruel. Vincent only differed from that ideal in his artistic nature, which impelled him to view the social harmony as a sort of religion and system of aesthetics ... I am sure that Julien was won over more by Vincent's socialism than by his painting, which he nevertheless venerated as a sort of visible manifestation of inner hopes. But in the meantime, before this era of happiness dawned, both of them were extremely poor, and each gave what he hadthe painter his canvases, and the tradesman his colours, his money and his table- to friends, to laborers, or to prostitutes who, when they received paintings, sold them to nothing to junk shops. And all this was done without the slightest self-interest for people they did not even know. ${ }^{6}$

According to Bernard, Tanguy was a 'childish utopian socialist', and he shared van Gogh's faith in utopia, a 'ère de félicitê..$^{7}$ Here, a message from one of van Gogh's Arles letters offers a connection between this utopian socialist and Japan:

Here my life will become more and more like a Japanese painter's, living close to nature like a petty tradesman. And that you well know, is a less lugubrious affair than the decadent's way. If I can live long enough, I shall be something like old Tanguy. ${ }^{8}$

To both Tanguy and van Gogh, Japanese painters were regarded as authentic inhabitants of the ideal society. Van Gogh's subjective understanding of Japanese society was clearly tinted by his idea of primitive socialism, a vision likewise overlapping with Tanguy's misguided interpretation. That is to say, the juxtaposition of Tanguy and the Japanese bonze was not mere whimsy, but rather the painting represented a vision of utopia shared by both men.

4 Peter Gay, The Bourgeois Experience : Victoria to Freud, 5 vols (New York: Oxford University Press, 1984), p. 143.

5 Vincent van Gogh, trans. Ronald de Leeuw, The letters of Vincent van Gogh, (London, Allen Lane: Penguin Press, 1996), p. 329.

6 Emile Bernard, 'Julien Tanguy dit le "Père Tanguy", Mercure de France. (16 December 1908), p. 606.

7 Kōdera, Tsukasa, 'Japan as Primitivistic Utopia: Van Gogh's Japonisme Portraits', Simiolus: Netherlands Quarterly for the History of Art, vol. 14, no. 3/4 (1984), pp. 189-208.

8 Ibid. 
Apart from the faith of Tanguy, another interesting aspect of the Portrait of Père Tanguy is the extraordinarily symmetrical pose the sitter strikes, which John House believes might have been borrowed from the typical pose of a Buddha figure. As Emile Bernard expresses in his article on Tanguy:

Vincent painted Tanguy's portrait around 1886. He showed him seated in a room lined with Japanese crépons, wearing a large planter's hat and in symmetrical frontal pose like a Buddha.'

In the history of modern portraiture, Tanguy's symmetrical pose is certainly an unusual one; additionally, Bernard's and House's comparison with a Buddha figure was not irrelevant. One of the illustrations in Louis Gonse's L'Art japonais, 'Statuette de bonze, par Hissatamma Oukousou' (Figure 8), is tremendously similar to the portrait in its frontal pose, especially in its use of clasped hands. ${ }^{10}$

The background prints of Portrait of Père Tanguy (Figure 7) essentially sum up van Gogh's aesthetic attitude towards Japan, including the utilisation of both Japanese landscape and portraiture. The first of these prints is Yoshitsune's Cherry Tree near the Noriyori shore (Figure 9), in which two figures plant seeds in the fields. The second is The Courtesan Takao of the Miuraya (Figure 10). The following two are slightly speculative, as no exact research has been done to demonstrate the origin of these prints. However, I found a strong connection between van Gogh's illustrations and numerous Japanese paintings. On the top of the painting, Mount Fuji might be reproduced by Mount Fuji from the Sagami River (Figure 11), as the shapes of reeds in the foreground and the artistic feature of Mount Fuji are quite similar. Furthermore, the print on the left side is derived from Morning Glories at Iriya in the Eastern Capital (Tôto Iriya asagao) (not pictured). The next one is even more difficult to track down, but based on the construction of the print, it is possible that it had its origins in The Nihon Embankment near the Yoshiwara, from the series Famous Places in Edi (Köto meisho) (Figure 12). Finally, the courtesan print on the right is actually his own copy, as mentioned above. In summary, we can see that van Gogh was deliberately trying to draw into his work many Japanese aesthetic elements. Spring is from the cherry tree, summer is from glories, autumn is from the Mount Fuji, and the snow seen in Yoshiwara is winter. All of these images reflect principal Japanese motifs. ${ }^{11}$

9 Emile Bernard, 'Julien Tanguy dit le 'Père Tanguy,' 'Mercure de France. (16 December 1908), p. 606.

10 Louis Gonses, L'Art japonais, vol. 2 (Paris: A. Quantin, 1883), p. 60.

11 Frist Center for the Visual Arts, Curator's Perspective: 'Vincent van Gogh and Japan' [Video file]. Presented by Simon Kelly, curator of modern and contemporary art, Saint Louis Art Museum (22 May 2014). Retrieved from vimeo.com/96116123. 


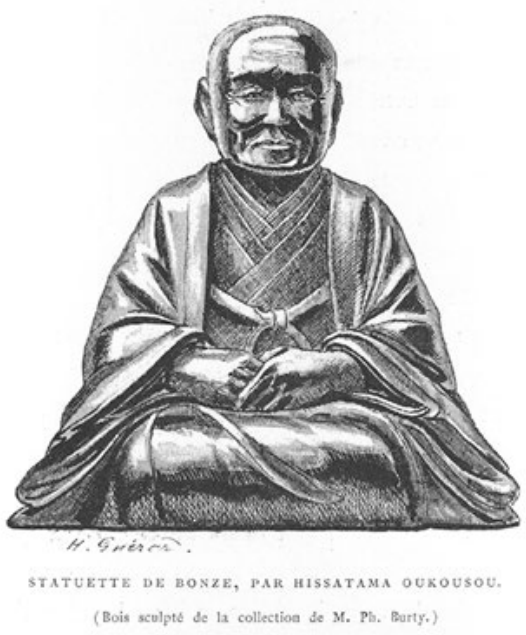

Figure 8: Louis Gonse. Statuette de bonze, Par Hissatama Oukousou.

Source: L'Art japonais, vol. 2 (Paris: A. Quentin 1883), p. 60.

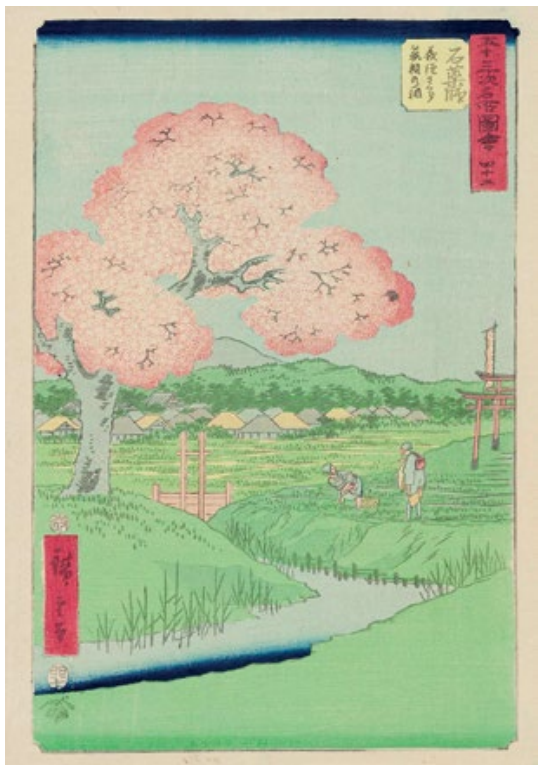

Figure 9: Utagawa Hiroshige, Yoshitsune's Cherry Tree near the Noriyori shore, 1885, woodcut, $36 \mathrm{~cm} \times 23 \mathrm{~cm}$.

Source: Van Gogh Museum, Amsterdam (Vincent van Gogh Foundation).

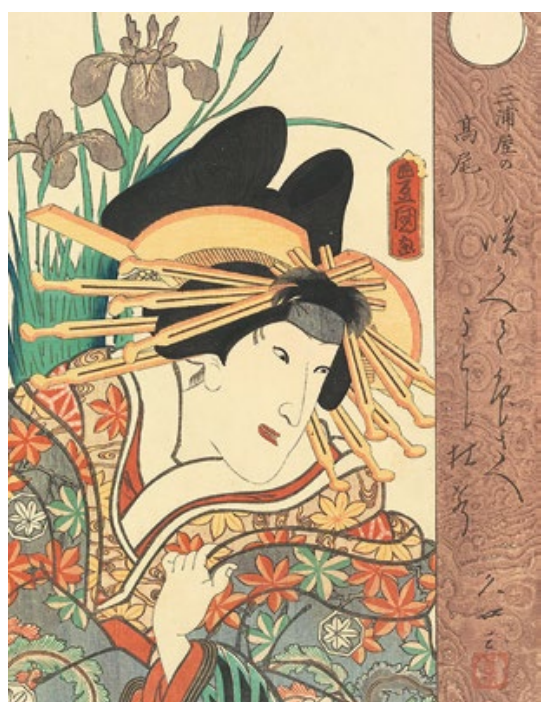

Figure 10: Utagawa Toyokuni III (1786-1865), The Courtesan Takao of the Miuraya, 1861.

Source: Van Gogh Museum, Amsterdam (Vincent van Gogh Foundation).

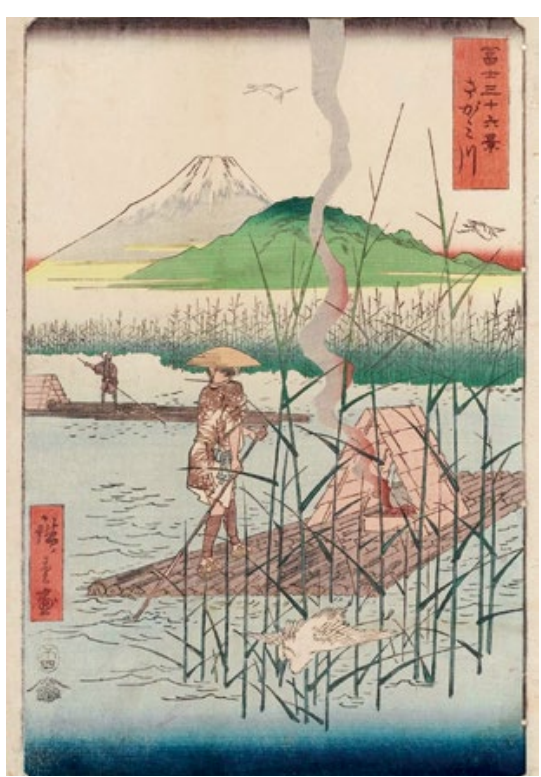

Figure 11: Utagawa Hiroshige, Mount Fuji from the Sagami River, 1858.

Source: Van Gogh Museum, Amsterdam (Vincent van Gogh Foundation). 


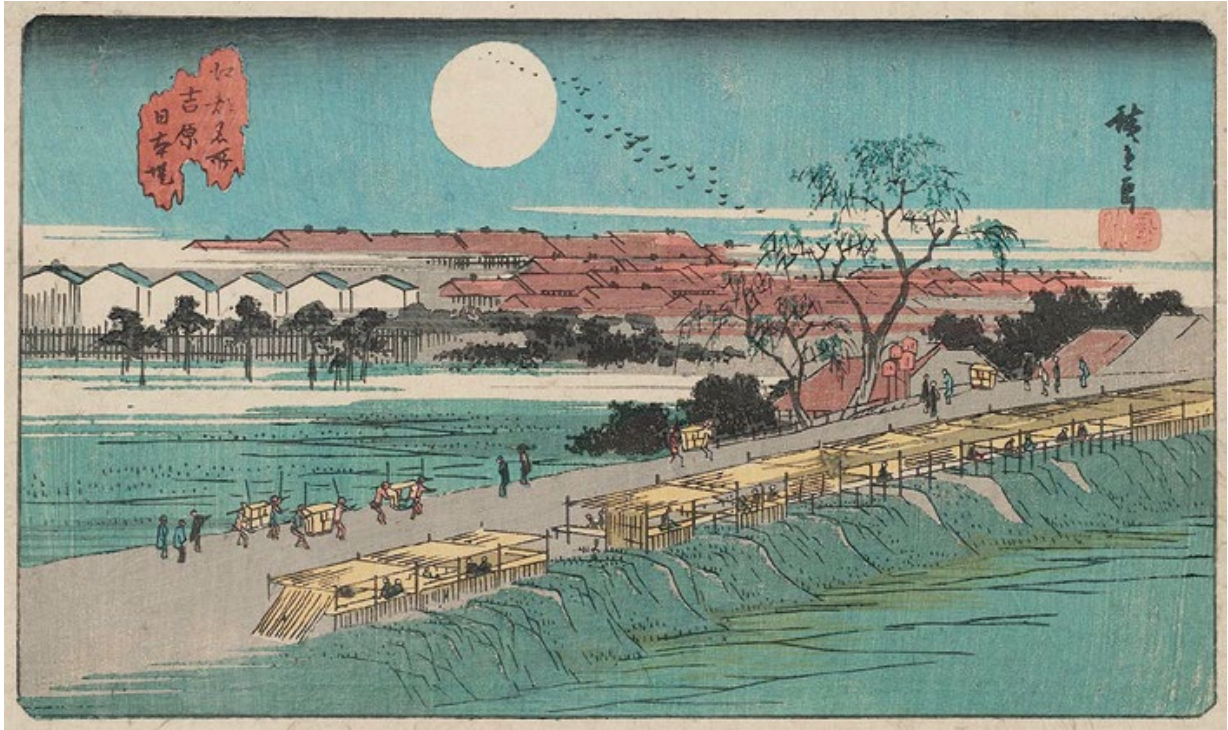

Figure 12: Utagawa Hiroshige, The Nihon Embankment near the Yoshiwara, 1857, woodcut, $34 \mathrm{~cm} \times 22 \mathrm{~cm}$.

Source: Van Gogh Museum, Amsterdam (Vincent van Gogh Foundation).

\section{Self-portrait Dedicated to Paul Gauguin}

Van Gogh was especially fond of portraiture when he lived in Arles. ${ }^{12}$ Self-portrait Dedicated to Paul Gauguin (Figure 13) is the one that reflects van Gogh's Japanese preference most clearly. ${ }^{13}$ At the end of September 1888, van Gogh painted a practice self-portrait, which he then sent to the artist Paul Gauguin. In it, he overtly identified himself with a Japanese monk. In a description of it to his brother Theo, he focused on the question of colour: 'my own ashen colouring' against 'a background of pale malachite'. However, to his sister Wil, he introduced an additional significant element: 'I also made a new portrait of myself, as a study, in which I look like a Japanese.'14 He also wrote to Gauguin: 'But as I also exaggerate my personality, I have in the first place aimed at the character of a simple bonze worshiping the Eternal Buddha.' The round head, slanted eyes and the nose are unmistakably the features of Japanese bonzes. In addition, one of the illustrations in Pierre Loti's Madame Chrysanthème probably had given him the physiognomic model for his self-portrait (Figure 14). He would have had little opportunity to see and study features of a Japanese person, so the illustrations and reproductions from books would have been important sources

12 Bogomila Welsh Ovcharov, 'Van Gogh at the Metropolitan. New York', The Burlington Magazine 127, no. 982 (1985).

13 Douglas Cooper, 'Two Japanese Prints from Vincent Van Gogh's Collection', The Burlington Magazine 99, no. 651 (1957).

14 Pickvance, Van Gogh in Arles, Metropolitan Museum of Art (New York, 2003), p. 203. 
for him. The clasped hands of the bonze in the reproduction in Gonse's L'Art japonais was not typical for a Japanese bonze, but for van Gogh, this posture would have been the ideal image of a bonze. Similar influences can be seen in another of van Gogh's Japanese aesthetic portraits, La Mousmé (Figure 15). ${ }^{15}$ Pierre Loti's description of the mouth of Mousmé ('moue' and 'frimousse') was not entirely true; however, it was the first and the only depiction of a Japanese girl. The lack of knowledge of a foreign country is not an advantage for one drawing the exotic; rather it is one of the preconditions for utopian thought as van Gogh illustrates with his art. ${ }^{16}$

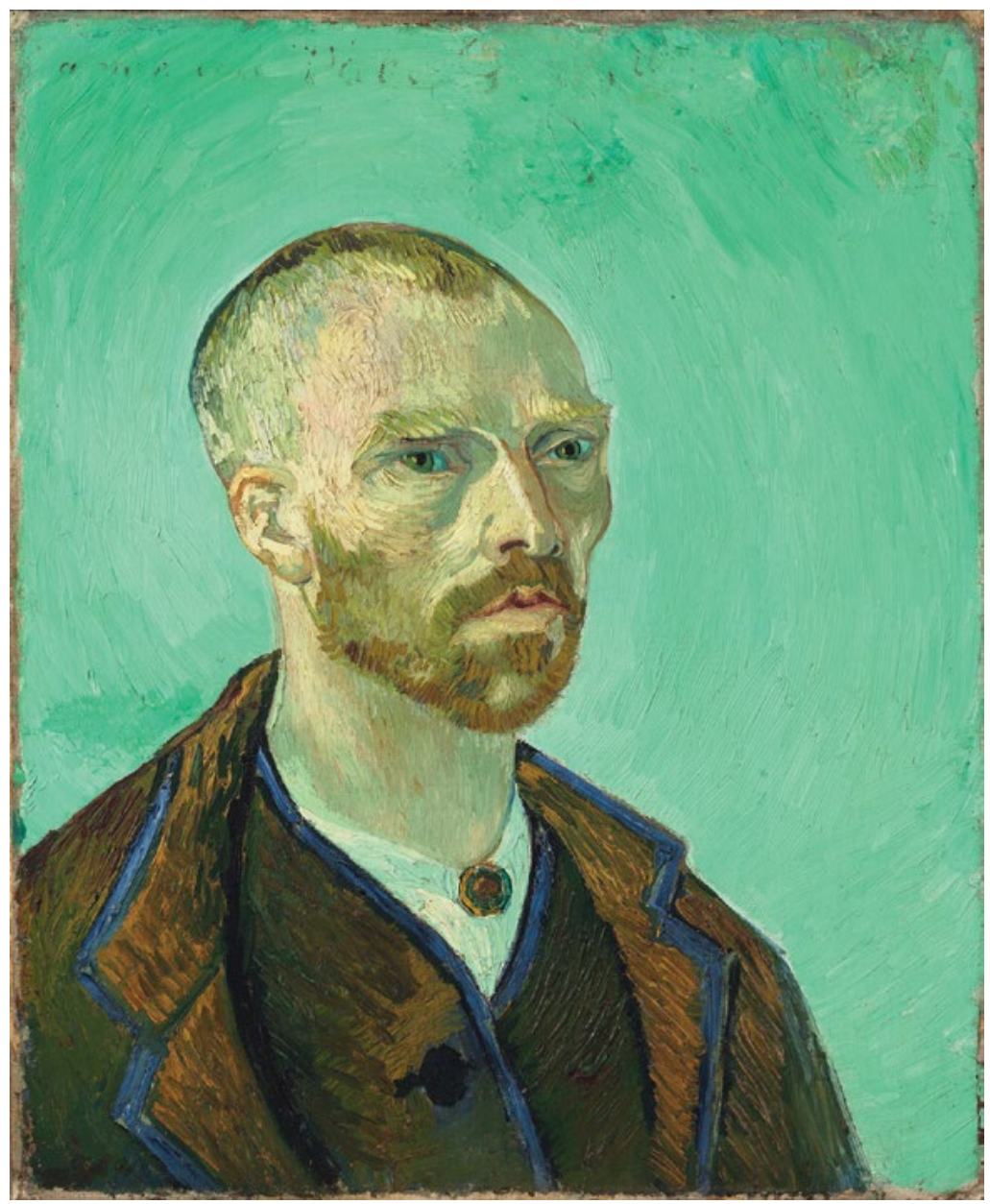

Figure 13: Vincent van Gogh (1853-1890), Self-Portrait Dedicated to Paul Gauguin, 1888, Oil on canvas, $61.5 \mathrm{~cm} \times 50.3 \mathrm{~cm}$.

Source: Harvard Art Museums/Fogg Museum.

15 Vincent van Gogh, 'La Mousmé, National Gallery of Art, www.nga.gov/collection/gallery/gg84/gg84-46626.html. 16 Kōdera, Tsukasa., 'Japan as Primitivistic Utopia: Van Gogh's Japonisme Portraits', Simiolus: Netherlands Quarterly for the History of Art, vol. 14, no. 3/4 (1984), pp. 189-208. 


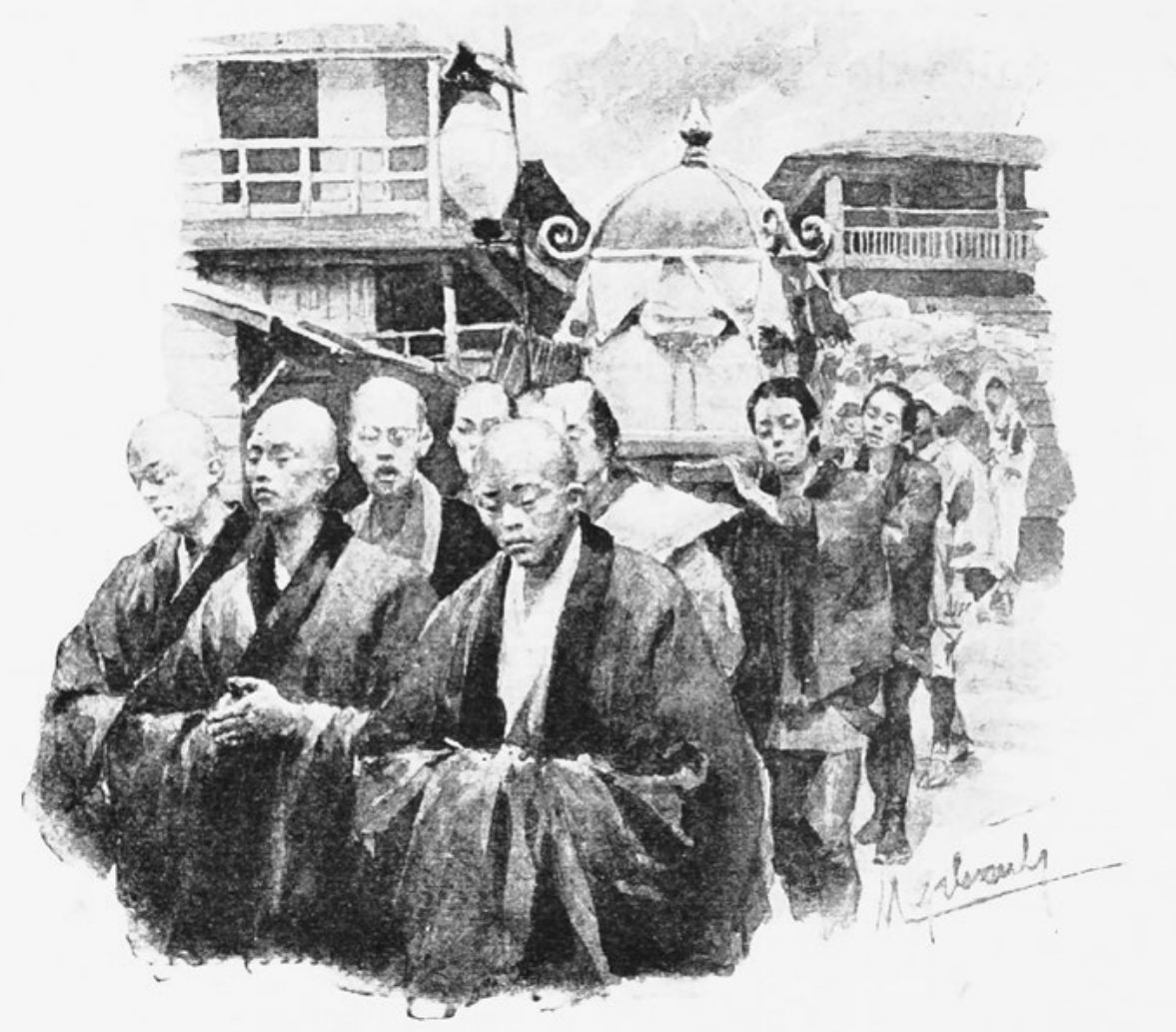

Figure 14: Felician Myrbach, Funeral procession, illustration. Source: Pierre Loti, Madame Chrysanthème (Paris: Calman Levy, 1888).

After Self-portrait with a Japanese print (not pictured), van Gogh's last Japonisme portrait, 'Japonais' ceased to be the model of his ideal society. While van Gogh's primitivistic utopia of 'Japon' might seem like a deluded and childish vision of Japan, it was this romantic dream, which van Gogh called 'enfantillage', that supported his creative activities during the most productive period of his life. Van Gogh was not alone; many of the artists around him at that time shared a similar fascination with Japan, including Claude Monet, Pierre Bonnard and Paul Gauguin. However, Japonism was most readily seen in the paintings of van Gogh, who experimented with Japanese artistic features in his portrayal of socialist issues. Even though van Gogh had limited access to Japanese artworks, he created his own unique way to express his 'Japon' aesthetics through his studies of Japanese motifs and philosophy. In van Gogh's artworks from his Japanese period, we not only see his outstanding painterly expression, but also, more significantly, the genuine admiration of the East from one of the most well-known of modern artists. 


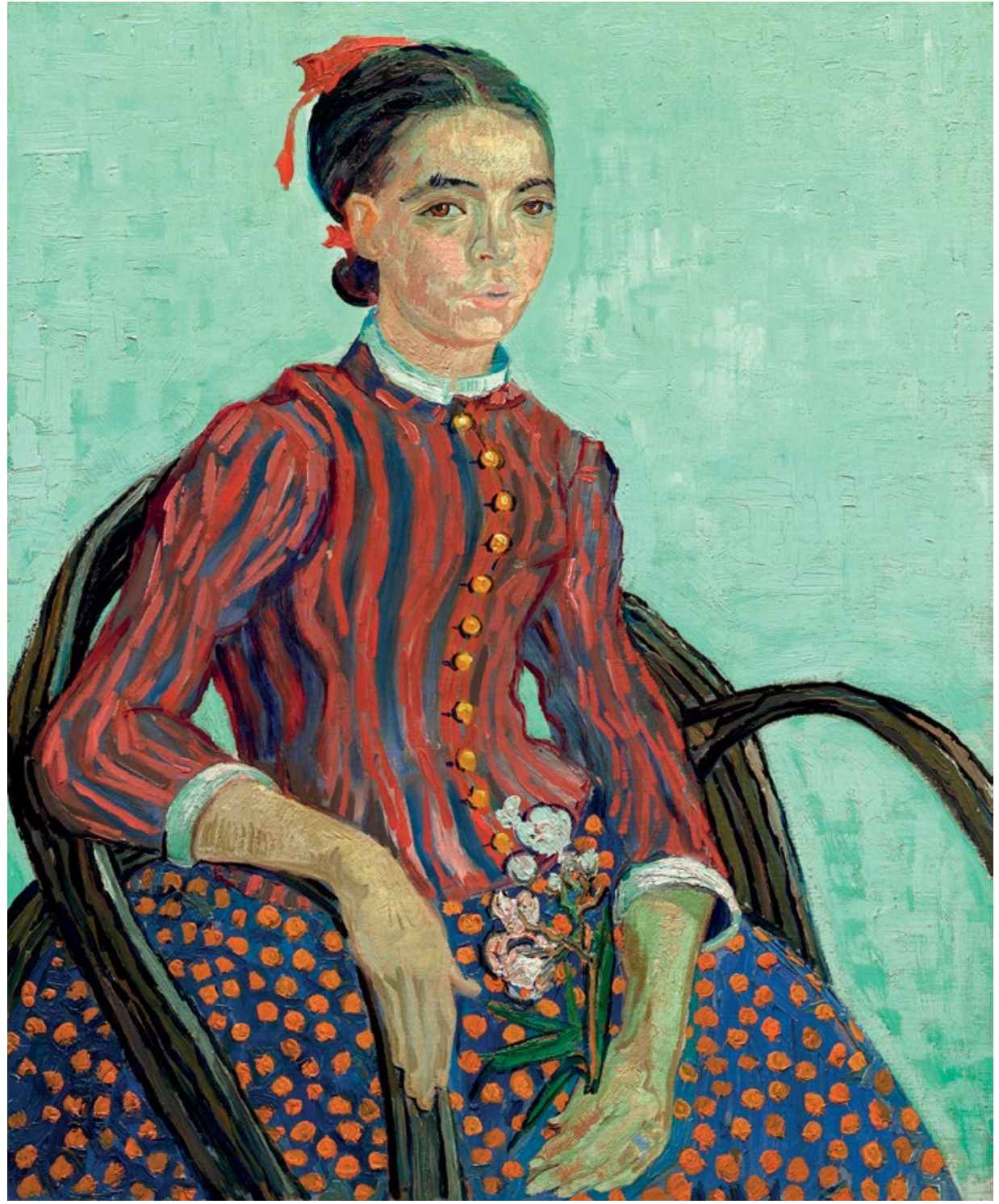

Figure 15: Vincent van Gogh (1853-1890), La Mousmé, 1888, oil on canvas, $73.3 \mathrm{~cm} \times 60.3 \mathrm{~cm}$.

Source: Chester Dale Collection, National Gallery of Art, Washington DC. 


\section{Bibliography}

Bernard, Emile. (1908, 16 December). 'Julien Tanguy dit le "Père Tanguy", Mercure de France, p. 606.

Cooper, Douglas. (1957). 'Two Japanese Prints from Vincent Van Gogh's Collection', The Burlington Magazine 99, no. 651.

Frist Center for the Visual Arts. (2014, 22 May). Curator's Perspective: 'Vincent van Gogh and Japan' [Video file]. Presented by Simon Kelly, curator of modern and contemporary art, Saint Louis Art Museum. Retrieved from vimeo. com/96116123.

Gay, Peter. (1984). The Bourgeois Experience: Victoria to Freud, 5 vols. New York: Oxford University Press.

Gonse, Louis. (1883). L’Art japonais, vol. 2. Paris: A. Quantin.

Kōdera, Tsukasa. (1984). 'Japan as Primitivistic Utopia: Van Gogh's Japonisme Portraits,' Simiolus: Netherlands Quarterly for the History of Art 14(3/4), 189208. doi.org/10.2307/3780577.

Pickvance, Ronald. (1984). Van Gogh in Arles. New York: Metropolitan Museum of Art Abrams.

van Gogh, Vincent. (1996). The letters of Vincent van Gogh. Edited by Ronald de Leeuw. London, Allen Lane: Penguin Press.

Welsh-Ovcharov, Bogomila. (1985). 'Van Gogh at the Metropolitan. New York', The Burlington Magazine 127, no. 982. 
This text is taken from The ANU Undergraduate Research Journal, Volume Eight, 2016, edited by Daniel McKay, published 2017 by ANU eView, The Australian National University, Canberra, Australia.

dx.doi.org/10.22459/AURJ.08.2016.19 